\title{
The Methods of Tea Waste Reutilization and Economic Benefits Analysis
}

\author{
Pin Gao ${ }^{1, \text { a) }}$, Yoshito Ogata ${ }^{2}$, Jin Liu ${ }^{1}$, Chang Song ${ }^{1}$ \\ ${ }^{1}$ Graduate School of Design, Kyushu University, Fukuoka 815-8540, Japan. \\ ${ }^{2}$ Department of Design Strategy, Faculty of Design, Kyushu University, Fukuoka 815-8540, Japan. \\ a)418480928@qq.com
}

\begin{abstract}
This study focused on the recycling of tea waste and developing circular economy of tea industry, through experiments and literature analysis, we found components of tea waste, and concluded that tea waste contains tea polyphenols, cellulose, lignin and other components. Molding experiment was performed on materials using the Hot Pressing Process, and the mechanical properties of the material after molding were tested by universal testing machine, so as to determine whether the material conformed to the standard of use; what's more, the advantages of reusing tea wastes were analyzed by cross contrasting with other man-made materials. The tea waste produced by tea beverage producers in Japan Kyushu area was taken as an example, to promote the recycling of waste, this paper established a Tea Waste Recycling System and used Cost Benefit Analysis to analyze the economic benefits to enterprises brought by tea waste recycling methods.
\end{abstract}

Keyword. Tea waste, Hot Pressing Process, Tea Waste Recycling System, Cost Benefit Analysis

\section{INTRODUCTION}

Environmental protection and efficient utilization of resources have been a very prominent issue in social development, taking China's timber resources as an example, in the solely 2015, China's insufficient commodity timber supply reached about 150 million cubic meters, with the growth of people's consumption to wood resources, the supply issue of wood resources will become more serious[1].

This study aimed to alleviate this problem, starting from the innovation angle of the material, the annual increasing tea waste (tea stalk and old tea produced in the process of industrial processing, and tea residue discharges from tea beverage plants) was taken as study example, and high temperature hot pressing processing technology was used to process material certain strength to achieve the role of [tea] replacing [wood], so as to alleviate the shortage of wood resources.

\section{INVESTIGATION AND LITERATURE ANALYSIS}

\subsection{Tea yield status}

Tea is a well-known and popular drink, however, whether it is tea or tea drinks, a great deal of waste are bound to be produced in the process of production, for example, tea production and processing in China, the processing and making of tea is a complex and rigorous process, fine tea needs layer upon layer selection, therefore, in the process of tea production, there will be a large number of accessories, such as tea stems, old tea and tea tree pruning branches, etc., according to the statistics, annual selection of tea waste was accounting for $20 \%$ of the total gross weight of tea[2]; in 2015, the total output of tea in China had reached 2 million 130 thousand tons, and continued to grow at an annual rate of $9.6 \%$. While for these wastes, most practices were to burn or bury them locally, and a small part of the tea stalk was picked out to pack in bags to be placed in a newly decorated room or new car to absorb odors. And, tea beverage factory, in the production process of tea beverage, will also produce a large number of tea waste. For example, tea beverage producer in Japan, in processing and production, second-picking and third- 
picking tea was often processed to be low-grade tea, so the quality was slightly lower compared to that of the original picking tea, and mechanical picking methods were often used in second-picking and third-picking, therefore, the tea was accompanied by a large number of tea stems. To observe the tea residue discharged from the tea beverage plant, the ratio of tea stem to tea was 1:4. Ito Park, the famous tea beverage producer in Japan, had produced 51 tons of tea waste from processing tea beverage in the only 2012. And $65 \%$ of them were buried for compost, $17 \%$ for heat recovery treatment, and the rest were used as a feed or as a material additive[3]. TRIAL, another chain supermarket in Japan, also produces tea beverages for sale, the amount of its tea produced waster per year reached 120 tons, to this end, the company needs to pay about high fees for tea waste processing every year.

\subsection{Material analysis}

By investigating existing research, it was found that the chemical constituents of tea are generally composed of 93\%-96.5\% organic compounds and 3.5\%-7.0\% inorganic compounds, mainly including proteins, amino acids, tea polyphenols, alkaloids and other chemicals[4]. And the main constituents of tea stem are cellulose, hemicellulose and lignin, as well as tea polyphenols, theaflavins, and caffeine , among them, the first three ingredients are crucial for material formation. Cellulose is one of the most widely distributed polysaccharides in nature, it is a substance that supports the plant, and the major component of plant cell walls. Hemicellulose and cellulose coexist in the cell walls of plants to protect the plant itself. Lignin is an intercellular bond, and its contents will directly affect the mechanical strength of the material after forming. Through a survey on previous researchers' studies, it was found that, in tea steams, in addition to hemicellulose content slightly higher than that of ordinary wood, the contents of cellulose and lignin are lower than those of general timber, about 30\%. Generally speaking, the higher the content, the better the performance of the forming board. The low contents of cellulose and lignin in tea steams determine that the mechanical properties of tea waste materials will be lower than that of wood-based panels[5].

\section{RESEARCH METHODS AND DATA ANALYSIS}

\subsection{Forming experiment and material comparison}

Because, the plant fiber contained in tea waster is similar to that of timbers, therefore, the method of high temperature hot pressing was used to process the tea waste, in order to meet the needs of the processing process, first of all, the moisture content of the material should be controlled between $5 \%$ and $8 \%$, for excessive moisture content would cause bubbles in the material during processing and affect mechanical strength. In terms of material fiber morphology, the tea waste were crushed and screened using a sieve, that is, the proper size of fiber could ensure the mechanical strength of the material after forming, after repeated experiments, it was found that the mechanical strength was highest after molding if determining to crush the material to 60 meshes. After crushing and screening, pour the material into the mixer for full mixing with the adhesive, the adhesive used in the experiment was urea formaldehyde resin adhesive, and the amount was $20 \%$. Pavement preloading was then carried out after mixing, the preload pressure value was set to $2.8 \mathrm{Mpa}$, after that, the materials were put in high temperature hot press for hot press molding. Tea waste is different from wood, high temperatures will destroy the tea material and cause it to become carbonized, so in the hot pressing process, parameters setting were: temperature $145^{\circ} \mathrm{C}$, pressure $18.5 \mathrm{mpa}$, hot pressing time $5 \mathrm{~min}$. After forming, the material was cut using a cutting saw, then mechanical test was performed using universal testing machine. In the process of material processing, same processing data were adopted to process the wood shavings and test its mechanical strength, and in this way, tea waste materials and wood materials were compared and analyzed. As shown in Table 1, each mechanical strength of artificial board made of tea waste material conformed to the national standard, it was not as good as wood chipboard in all tests caused by low fiber component in tea waste, therefore, proper increase of material density could also improve the strength of sheet metal after molding.

Although the mechanical strength of the material was lower than that of wood shavings, from the formaldehyde emission release amount in the last item in the table, it was found that when the tea was abandoned, its formaldehyde emission was much lower than that of wood shavings. This is because that the physical and chemical properties of tea and tea stem materials have an adsorption effect on formaldehyde, and inhibit the production of free formaldehyde. According to measurement, the formaldehyde emission from tea waste producing board was reduced by $78 \%$ compared to wood particleboard[6]. 
TABLE 1. Test report on properties of wood-based panels

\begin{tabular}{|c|c|c|c|c|c|}
\hline $\begin{array}{l}\text { Sample } \\
\text { name }\end{array}$ & & \multicolumn{2}{|c|}{ Tea Stalk Particleboard } & $\begin{array}{c}\text { Sample } \\
\text { specification }\end{array}$ & $320 \times 340 \times 13=$ \\
\hline & & & & $\begin{array}{l}\text { Inspection } \\
\text { basis }\end{array}$ & $\begin{array}{c}\text { GB18580-2001 } \\
\text { GB/T4897.3-200: }\end{array}$ \\
\hline \multicolumn{2}{|c|}{ Inspection item } & Unit & Standard value & Test result & Result judgment \\
\hline \multicolumn{2}{|c|}{ Water content } & $\%$ & $4 \sim 13$ & 4.7 & $\begin{array}{l}\text { Meet the standarc } \\
\text { requirements }\end{array}$ \\
\hline \multicolumn{2}{|c|}{ Density } & & $0.4 \sim 0.9$ & 0.9 & \begin{tabular}{|c} 
Meet the standarc \\
requirements
\end{tabular} \\
\hline \multirow{2}{*}{\multicolumn{2}{|c|}{ MOR }} & \multirow{2}{*}{$\mathrm{MPa}$} & $\bar{x} \geqslant 13$ & $\bar{X}: 13.2$ & $\begin{array}{c}\text { Meet the standarc } \\
\text { requirements }\end{array}$ \\
\hline & & & $X_{\min } \geqslant 10.4$ & $X_{\min }: 10.8$ & $\begin{array}{c}\text { Meet the standarc } \\
\text { requirements }\end{array}$ \\
\hline \multicolumn{2}{|c|}{ MOE } & MPa & $\geqslant 1600$ (板㫗 13〜20 man) & 1632 & $\begin{array}{l}\text { Meet the standarc } \\
\text { requirements }\end{array}$ \\
\hline \multirow{2}{*}{\multicolumn{2}{|c|}{ IB }} & \multirow{2}{*}{$\mathrm{MPa}$} & $\bar{x} \geqslant 0.35$ & $\bar{X}: 0.37$ & $\begin{array}{c}\text { Meet the standarc } \\
\text { requirements }\end{array}$ \\
\hline & & & $X_{\min } \geqslant 0.28$ & $X_{\min } 0.3$ & $\begin{array}{c}\text { Meet the standarc } \\
\text { requirements }\end{array}$ \\
\hline \multirow{4}{*}{$\begin{array}{c}\text { Screw } \\
\text { holding } \\
\text { capability }\end{array}$} & \multirow{2}{*}{ Plate edge } & \multirow{4}{*}{$\mathrm{N}$} & $\bar{X} \geqslant 600$ & $\bar{X}: 2273$ & $\begin{array}{c}\text { Meet the standarc } \\
\text { requirements }\end{array}$ \\
\hline & & & $X_{\text {ain }} \geqslant 480$ & $X_{\min } 1573$ & $\begin{array}{c}\text { Meet the standarc } \\
\text { requirements }\end{array}$ \\
\hline & \multirow{2}{*}{ Face } & & $\bar{X} \geqslant 900$ & $\bar{X}: 2130$ & $\begin{array}{l}\text { Meet the standarc } \\
\text { requirements }\end{array}$ \\
\hline & & & $X_{\text {ain }} \geqslant 720$ & $X_{\min } 1994$ & \begin{tabular}{|c}
$\begin{array}{c}\text { Meet the standarc } \\
\text { requirements }\end{array}$ \\
\end{tabular} \\
\hline \multicolumn{2}{|c|}{$\begin{array}{l}\text { Formaldehyde } \\
\text { emission }\end{array}$} & $\mathrm{Mg} / 100 \mathrm{~g}$ & $\leqslant 9.0(\mathrm{E} 1)$ & 2.0 & $\begin{array}{c}\text { Meet the standarc } \\
\text { requirements }\end{array}$ \\
\hline
\end{tabular}

\begin{tabular}{|c|c|c|c|c|c|}
\hline $\begin{array}{c}\text { Sample } \\
\text { name }\end{array}$ & \multicolumn{3}{|c|}{ Wood particleboard } & $\begin{array}{c}\text { Sample } \\
\text { specification }\end{array}$ & $300 \times 300 \times 15 \mathrm{~mm}$ \\
\hline & & & & $\begin{array}{l}\text { Inspection } \\
\text { basis }\end{array}$ & $\begin{array}{c}\text { GBI8580-2001 } \\
\text { GB/T4897.3-2003 }\end{array}$ \\
\hline \multicolumn{2}{|c|}{ Inspection item } & Unit & Standard value & Test result & Result judgment \\
\hline \multicolumn{2}{|c|}{ Water content } & $\%$ & $4 \sim 13$ & 7.8 & $\begin{array}{l}\text { Meet the standard } \\
\text { requirements }\end{array}$ \\
\hline \multicolumn{2}{|c|}{ Density } & & $0.4 \sim 0.9$ & 0.9 & $\begin{array}{l}\text { Meet the standard } \\
\text { requirements }\end{array}$ \\
\hline \multirow{2}{*}{\multicolumn{2}{|c|}{ MOR }} & \multirow{2}{*}{$\mathrm{MPa}$} & $\bar{X} \geqslant 13$ & $\bar{X}: 35$ & $\begin{array}{l}\text { Meet the standard } \\
\text { requirements }\end{array}$ \\
\hline & & & $X_{\min } \geqslant 10.4$ & $X_{\text {nin }}: 28$ & $\begin{array}{l}\text { Meet the standard } \\
\text { requirements }\end{array}$ \\
\hline \multicolumn{2}{|c|}{ MOE } & $\mathrm{MPa}$ & $\geqslant 1600$ (被原 $13 \sim 20 \mathrm{~mm}$ ) & 6638 & $\begin{array}{l}\text { Meet the standard } \\
\text { requirements }\end{array}$ \\
\hline \multirow{2}{*}{\multicolumn{2}{|c|}{ IB }} & \multirow{2}{*}{$\mathrm{MPa}$} & $\bar{X} \geqslant 0.35$ & $\bar{X}: 0.7$ & $\begin{array}{l}\text { Meet the standard } \\
\text { requirements }\end{array}$ \\
\hline & & & $X_{\min } \geqslant 0.28$ & $X_{\operatorname{mint}} 0.42$ & $\begin{array}{l}\text { Meet the standard } \\
\text { requirements }\end{array}$ \\
\hline \multirow{4}{*}{$\begin{array}{c}\text { Serew } \\
\text { holding } \\
\text { capability }\end{array}$} & \multirow{2}{*}{ Plate edge } & \multirow{4}{*}{$\mathrm{N}$} & $\bar{X} \geqslant 600$ & $\bar{X}: 2179$ & $\begin{array}{l}\text { Meet the standard } \\
\text { requirements }\end{array}$ \\
\hline & & & $X_{\text {ain }} \geqslant 480$ & Xmin: 1811 & $\begin{array}{l}\text { Meet the standard } \\
\text { requirements }\end{array}$ \\
\hline & \multirow{2}{*}{ Face } & & $\bar{X} \geqslant 900$ & $\bar{X}: 3521$ & $\begin{array}{l}\text { Meet the standard } \\
\text { requirements }\end{array}$ \\
\hline & & & $X_{\min } \geqslant 720$ & Xmint: 3390 & $\begin{array}{l}\text { Meet the standard } \\
\text { requirements }\end{array}$ \\
\hline \multicolumn{2}{|c|}{$\begin{array}{l}\text { Formaldehyde } \\
\text { emission }\end{array}$} & $\mathrm{Mg} / 100 \mathrm{~g}$ & $\leqslant 9.0$ (E1) & 8.9 & $\begin{array}{l}\text { Meet the standard } \\
\text { requirements }\end{array}$ \\
\hline
\end{tabular}

As shown in figure 1, tea waste material differs from general artificial panel, such as chipboard and density board. This kind of artificial sheet can only be processed solely, like using artificial panel to produce panel furniture. On the contrary, Tea waste material has more fine fiber morphology, which means it can be processed into other forms apart from furniture production. In this case, it has much more processing possibilities compared with general artificial panel.

As shown in figure 2, tea waste material presses sheets by various tea species, and each sheet has its own texture and odor. By flexibly applying these differences can create tea waste products with various textures and color changes. Besides, tea sheets have various odors, which can meet the requirement of personalized customization from different people in different needs.
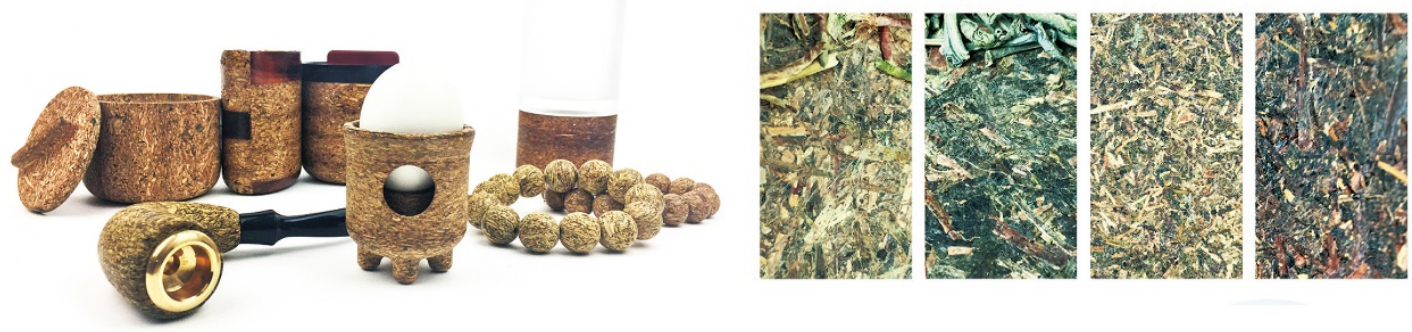

FIGURE 1. 2. Tea waste products and different surface texture

Tea stem has a considerable amount of aroma substance, and tea aroma is declined gradually from the first leaf to the third leaf, while the highest concentration is in tea stem. Tea aroma material is mainly in the chief vein of tea stem and tender leaf, and vascular bundle in tea stem is the main transfusion tissue of nutrient and aroma. Most material contained is water solubility, which means aroma will be transferred into leaves from stems by evaporation water in tea's processing. And in the process of processing, only the tea with tea stem can produce the tea with high aroma and rich taste[7].

Tea waste products are made from stems, and with its unique tea odor, it will lead users to associate with tea drinking behavior during using, and its order is the strongest feature differing from other artificial materials. 


\subsection{Tea waste recycling system}

As shown in figure 3, it was the tea waste recycling system constructed according to the material processing experiment, the purpose of the system was to change the practice of direct waste dumping to make tea waste produced in the production process reprocessed to form a new commodity to change the process of making tea from production to marketing from unidirectional structure to cyclic structure, so as to reduce the impact of waste disposal on environment and improve the value of waste utilization.

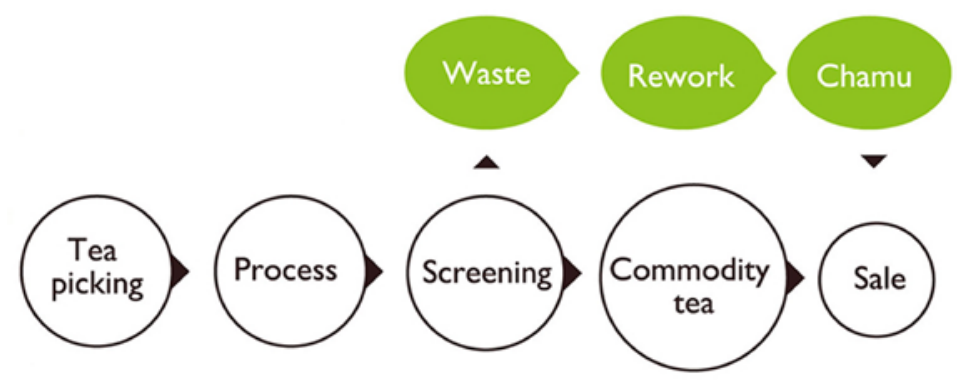

FIGURE 3. Tea waste recycling system

\subsection{Cost benefit analysis of tea waste}

At present, domestic and international researches on the use of producing waste materials into new materials are mainly concerned with improving or inventing a new technology to improve waste utilization and added value. However, this approach does not intuitively show how economic benefits can be generated by using this approach. In this paper, cost-benefit analysis was used to discuss the economic benefits of the construction of recycling system for tea waste while conducting machining experiments on tea waste.

Cost benefit analysis is a kind of economic decision-making method used frequently when an enterprise or government makes an investment decision, in this method, all the costs and benefits of an investment project or decision are listed and quantified; meanwhile, cost benefit analysis is also used to assess those contents difficult to quantify, such as social benefit, ecological benefit and indirect cost benefit, etc.. [8] In this paper, the tea beverage factory was taken as example to analyze the direct required costs and direct produced economic benefits by the tea waste recycling system constructed.

\subsubsection{Cost structure}

In view of the direct cost of the project, it mainly includes direct and indirect costs, direct costs are mainly equipment purchase and maintenance costs, staff training and wages, operating supplies, utilities and transportation management fees. Indirect costs include the expenses required for dangers and accidents occurred in equipment use process, for industrial processing equipment is always accompanied by certain risks in the process of production and processing. In addition to accident risks, there are also certain costs for the use of processing sites, for example, the effects of noise from the use of the equipment on the surrounding environment and on the efficiency of other employees. Compared with direct cost assessment, indirect cost evaluation is more subjective, the evaluation values fluctuate frequently, therefore, in this paper, the analysis was not done for those.

\subsubsection{Project revenue structure}

As mentioned above, there was possibility of tea waste processed into artificial boards, and it proved that the mechanical strength of sheet metal after molding met the national standard. In this part, the mas production of tea waste into artificial board was expected, and according to the current market price, adjustment was made, here, we assumed the proceeds of all sales of tea waste processing boards were used as direct economic benefits for estimation. 


\subsubsection{Project analysis}

For example, TRIAL, the large chain supermarket in Japan, the supermarket produces its own tea drinks and sells them, the annual tea waste production is about 120 tons, in this paper, it was planned to construct a tea waste recycling system in the company to improve enterprise economic benefits. In terms of the cost of system construction, as TRIAL belonged to self production and sale, therefore, the site fees, transportation costs and management fees were not calculated, the duration of the project was 10 years, the construction period of the project was 1 year, 1 year later, production and sales would begin. In the first year of the initial stage of the project, total investment in cost of equipment, material consumption, labor costs and energy consumption was 401 thousand and 900 yuan, thereafter, the cost of the initial equipment investment was removed, it was 304 thousand and 178 yuan per year.

In terms of income, the corporate annual discharge of tea waste was 120 tons, based on national standard, the annual artificial plates production was about 3650 pieces, calculated at 180 yuan market price, the annual direct economic benefit was 657 thousand yuan. According to the results of the survey and prediction in the paper, costbenefit analysis was used to calculate cash flow and present value of tea waste investment projects (detailed in table 2).

TABLE 2. The investment project cash flow and net present value calculation table

\begin{tabular}{|c|c|c|c|c|c|c|c|}
\hline $\begin{array}{c}\text { Serial } \\
\text { number }\end{array}$ & $\mathbf{1}$ & $\mathbf{2}$ & $\mathbf{3}$ & $\mathbf{4}$ & $\mathbf{5}$ & $\mathbf{6}$ & $\mathbf{7}$ \\
\hline item & $\begin{array}{c}\text { Cash } \\
\text { disbursements }\end{array}$ & $\begin{array}{c}\text { Cash } \\
\text { receipts }\end{array}$ & Depreciation & Net cash flow & $\begin{array}{c}\text { Cumulative } \\
\text { NCF }\end{array}$ & $\begin{array}{c}\text { Net } \\
\text { present } \\
\text { value }\end{array}$ & Cumulative NPV \\
\hline Total & 3139502 & 5913000 & 79470 & 1846786 & & 1166115 & \\
\hline $\mathbf{1}$ & 401900 & & & -401900 & -401900 & -401900 & -401900 \\
\hline $\mathbf{2}$ & 304178 & 657000 & 8830 & 249854 & -153090 & 232685 & -171957 \\
\hline $\mathbf{3}$ & 304178 & 657000 & 8830 & 249854 & 98641 & 215580 & 43623 \\
\hline $\mathbf{4}$ & 304178 & 657000 & 8830 & 249854 & 350013 & 199481 & 243104 \\
\hline $\mathbf{5}$ & 304178 & 657000 & 8830 & 249854 & 601565 & 184941 & 428111 \\
\hline $\mathbf{6}$ & 304178 & 657000 & 8830 & 249854 & 853350 & 171102 & 599214 \\
\hline $\mathbf{7}$ & 304178 & 657000 & 8830 & 249854 & 1104971 & 158521 & 757735 \\
\hline $\mathbf{8}$ & 304178 & 657000 & 8830 & 249854 & 1356592 & 146695 & 904429 \\
\hline $\mathbf{9}$ & 304178 & 657000 & 8830 & 249854 & 1608212 & 135875 & 1040305 \\
\hline $\mathbf{1 0}$ & 304178 & 657000 & 8830 & 249854 & 1859833 & 125810 & 1166115 \\
\hline
\end{tabular}

Static payback period (pp): the static payback period is the time needed to recover the initial investment funds including the construction period[9], as shown in the figure, in the third year of project investment, the accumulated net present value was changed from negative to positive, so the project's static payback period was three years.

Net present value (NPA):The net present value is the difference between the investment project and original investment present value under the discount rate of $8 \%$, the evaluation method enables the investment project to be feasible when the NPV is greater than 0 , and the greater the value of NPV, the better the efficiency of the investment project; The calculation formula of net present value is as follows: $\mathbf{N P V}=\sum \mathbf{N C F i}^{*}(\mathbf{1}+\mathbf{8} \%)^{\wedge}(\mathbf{- i})$, NCF is net cash flow, and I is the project life. According to the calculation, the net present value of the project was 1 million 166 thousand and 115 yuan.

As shown in table 2, the net present value of the investment project of tea waste recycling system was 1 million 166thousand and 115 yuan, including the 3-year static recovery period in the construction initial period, compared to the 10 year duration of the project, its payback period was short and the project profitability was high. From the point of view of input and output, the output of the investment project was greater than the input, which could improve waste utilization efficiency to establish a positive image for enterprises while ensuring economic benefits, and it reflected the necessity of the establishment of the investment project. 


\section{CONCLUSION}

This paper discussed the possibility of processing and forming countermeasures for tea waste, and by tests, it had showed that the artificial board made of tea waste had the strength conforming to the national man-made board standard, so where raw materials and equipment met the requirements, they could be commercialized. Moreover, the cost-benefit analysis was adopted to calculate and verify that the investment in tea waste recycling project by enterprises had considerable direct economic benefits. However, there are also some shortcomings in this study, for example, in the utilization of tea waste, the paper only analyzed the possibility of tea waste sheet molding and commercialization, but tea waste was also suitable for reprocessing or other processing, as mentioned above, forming different shapes of products through reprocessing or primary molding by press tool to make tea waste products achieve utilization. These methods of use have been preliminarily validated, but, further improvement is needed to make the products meet the requirements of commercialization due to restrictions on processing equipment. While in the cost-benefit analysis section, the paper only analyzed and calculated direct economic costs and direct economic benefits, without analysis on parts difficult to be quantified, such as social benefits, ecological benefits, etc., this needs further strengthening in the future research.

\section{REFERENCES}

1. Gao Pin, Study on reuse of Non adhesive for tea wastes based on hot pressing process, J. Building materials and decoration. 2017.

2. Gao Pin, [Chamu] furniture- Design of panel furniture with tea stems, J. Business. 2016, pp. 263-264.

3. Reference to a chapter in an edited book: http://www.3r-suishinkyogikai.jp/event/data/H26S2.pdf

4. Cai Xiaohong, Tea and tea products waste on the formaldehyde adsorption kinetics of particleboard development and environmental protection, D. Zhejiang: Zhejiang University, 2010:1-50

5. Su Tuan, Study on the technology of tea stalk particleboard and the control mechanism of formaldehyde emission, D. Fujian Agricultural University, 2012:13-14

6. Gao Pin. Environmental friendly household articles design taking tea stems as raw materals, D. Beijing University of Technology, 2016:06-17

7. Information on http: baike.so.com/doc/5870492-6083352.html

8. Information on http: wiki.mbalib.com/zh-tw/ Cost benefit analysis

9. Li Yanqiong, Cost-benefit analysis of commonweal water conservancy project base on sustainable development: A Case Study of Xingjiawang reservoir reinforcement project, D. Central South University Of Forestory and Technology, 2014:10-20 